\title{
Growth and population structure in two species of bivalves (Nuculanidae) from the deep sea
}

\author{
J. A. Hutchings and R. L. Haedrich \\ Department of Biology and Newioundland Institute for Cold Ocean Science, Memorial University of Newfoundland, St. John's, \\ Newfoundland A1B 3X9, Canada
}

\begin{abstract}
Numerous specimens of Nuculana pernula and Yoldia thraciaeformis (Bivalvia: Nuculanidae) were collected from depths of 895 to $1500 \mathrm{~m}$ in the Northwest Atlantic Ocean off Newfoundland. Sizes attained by both species approach or exceed previously recorded maximum lengths. The populations are dominated by large individuals. Little overlap in lengths between the cohabiting species is observed. Boring gastropods and benthic fish are identified as predators of small bivalves at these depths. Rapid growth rates early in life, heavy predation on young individuals, and size-related mechanisms reducing niche overlap are possible explanations of the observed size structure.
\end{abstract}

\section{INTRODUCTION}

Numerous specimens of Nuculana pernula Müller and Yoldia thraciaeformis Storer (Bivalvia: Nuculanidae) were among the invertebrate fauna found at depths to $1500 \mathrm{~m}$ in Carson Canyon, a submarine canyon at $45^{\circ} 30^{\prime} \mathrm{N}$ off the southeastern Grand Banks of Newfoundland. These 2 species occur in the western North Atlantic from the Arctic Ocean to the New England coast and in the eastern north Pacific from the Arctic Ocean to coastal British Columbia (Theroux and Wigley, 1983). N. pernula is also found off eastern Siberia (Skalkin and Tabunkov, 1969). $N$. pernula and $Y$. thraciaeformis have recorded bathymetric ranges of 3 to $1643 \mathrm{~m}$ and 18 to $418 \mathrm{~m}$ respectively (Theroux and Wigley, 1983) but information on deep-sea populations remains scanty. Tabunkov (1974) reports that temperature, rather than depth, limits the vertical distribution of $N$. pernula.

Our samples are sufficiently large so that growth and population size structure in Nuculana pernula and Yoldia thraciaeformis from a deep ocean locale can be assessed. Because these 2 presumed ecologically similar species were collected together, we are afforded an opportunity to examine which factors may mediate competition. We postulate the possibility of differential size distributions as playing an important role.

Seasonal changes in rate of shell formation affect the surface morphology of molluscan shells (Byran, 1969;
Theisen, 1973; Lutz, 1976). Reductions in feeding activity and calcification rates at low temperatures produce shell rings that can be used for age determination (Williamson and Kendall, 1981). Some bivalves are known to deposit shell lines during spawning (Jones, 1980; Gallucci and Gallucci, 1982). At the oceanic depths from which our samples come seasonal signals are thought to be damped, yet growth checks and banding are a distinctive feature of the external shell surface of Nuculana pernula and Yoldia thraciaeformis. The pattern in which bands have been deposited suggests that the event(s) that produce(s) them recur(s) with regularity throughout the lives of these nuculanids. We consider the bands as valid indicators of growth and argue that age classes can be determined on the basis of external and internal banding.

\section{MATERIALS AND METHODS}

Collections were made on cruises of the M/V Gadus Atlantica' during 1980 and 1981. Specimens of 183 Nuculana pernula and 149 Yoldia thraciaeformis were taken in a $12.5 \mathrm{~m}$ Gulf-of-Mexico shrimp trawl from 7 sampling stations in Carson Canyon (Fig. 1, Table 1). Neither species was taken at depths shallower than $895 \mathrm{~m}$ in benthic grabs and trawls near the head of the canyon (data of Houston and Haedrich, ms). The trawl 
Table 1. Collection sites of Nuculana pernula and Yoldia thraciaeformis in Carson Canyon

\begin{tabular}{|c|c|c|c|c|c|c|}
\hline $\begin{array}{l}\text { Station } \\
\text { number }\end{array}$ & Date & Latitude & Longitude & $\begin{array}{l}\text { Trawl depth } \\
\text { (m) }\end{array}$ & $\begin{array}{l}\text { Number of } \\
N \text {. pernula }\end{array}$ & $\begin{array}{l}\text { Number of } \\
Y . \text { thracideformis }\end{array}$ \\
\hline 816 & June 3,1980 & $45^{\circ} 23^{\prime} \mathrm{N}$ & $48^{\circ} 31^{\prime} \mathrm{W}$ & 0895-0905 & 4 & 0 \\
\hline 838 & June 4,1980 & $45^{\circ} 18^{\prime} \mathrm{N}$ & $48^{\circ} 35^{\prime} \mathrm{W}$ & $1420-1500$ & 32 & 85 \\
\hline 839 & June 4,1980 & $45^{\circ} 20^{\prime} \mathrm{N}$ & $48^{\circ} 36^{\prime} W$ & $1020-1200$ & 23 & 35 \\
\hline 853 & June 5,1980 & $45^{\circ} 18^{\prime} \mathrm{N}$ & $48^{\circ} 33^{\prime} \mathrm{W}$ & $1220-1280$ & 101 & 20 \\
\hline 865 & June 8,1980 & $45^{\circ} 24^{\prime} \mathrm{N}$ & $48^{\circ} 35^{\prime} \mathrm{W}$ & $1000-1050$ & 18 & 9 \\
\hline 962 & May 16,1981 & $45^{\circ} 33^{\prime} \mathrm{N}$ & $48^{\circ} 10^{\prime} \mathrm{W}$ & $1290-1320$ & 1 & 0 \\
\hline \multirow[t]{2}{*}{964} & May 16,1981 & $45^{\circ} 36^{\prime} \mathrm{N}$ & $47^{\circ} 56^{\prime} \mathrm{W}$ & $1460-1490$ & 4 & 0 \\
\hline & & & & Total & 183 & 149 \\
\hline
\end{tabular}

has $3.7 \mathrm{~cm}$ stretch mesh in the body and a $2.5 \mathrm{~cm}$ heavy knotted liner in the codend which retains very copious amounts of mud containing very small specimens. The gear and its handling follow standardized methods adopted in our deep ocean work (Haedrich et al., 1980). Tows were 20 or $30 \mathrm{~min}$ in duration. Water temperature and salinity measurements at $1000 \mathrm{~m}$ were $3.5^{\circ} \mathrm{C}$ and $35.0 \mathrm{ppt}$ in May, 1981 , at $45^{\circ} 31^{\prime} \mathrm{N}$ $48^{\circ} 20^{\prime} \mathrm{W}$. Bottom substrate retained in dead shells consisted of a muddy ooze. Material was fixed in $10 \%$ formalin at time of capture. All material, both live and dead shells, was kept but only data from live speci- mens were used to construct the growth curves. Counts, weights, and measurements were done ashore in the laboratory. Measurements of total shell length, maximum width and maximum height were made to the nearest $0.1 \mathrm{~mm}$ using dial calipers following Bayne (1976). There were no significant differences in size of individuals between samples, and thus the data were lumped for the overall analyses.

Valves from 50 Yoldia were longitudinally sectioned along the antero-posterior axis and examined under a compound microscope for growth bands as illustrated by Lutz (1976). Sections which did not pass through the

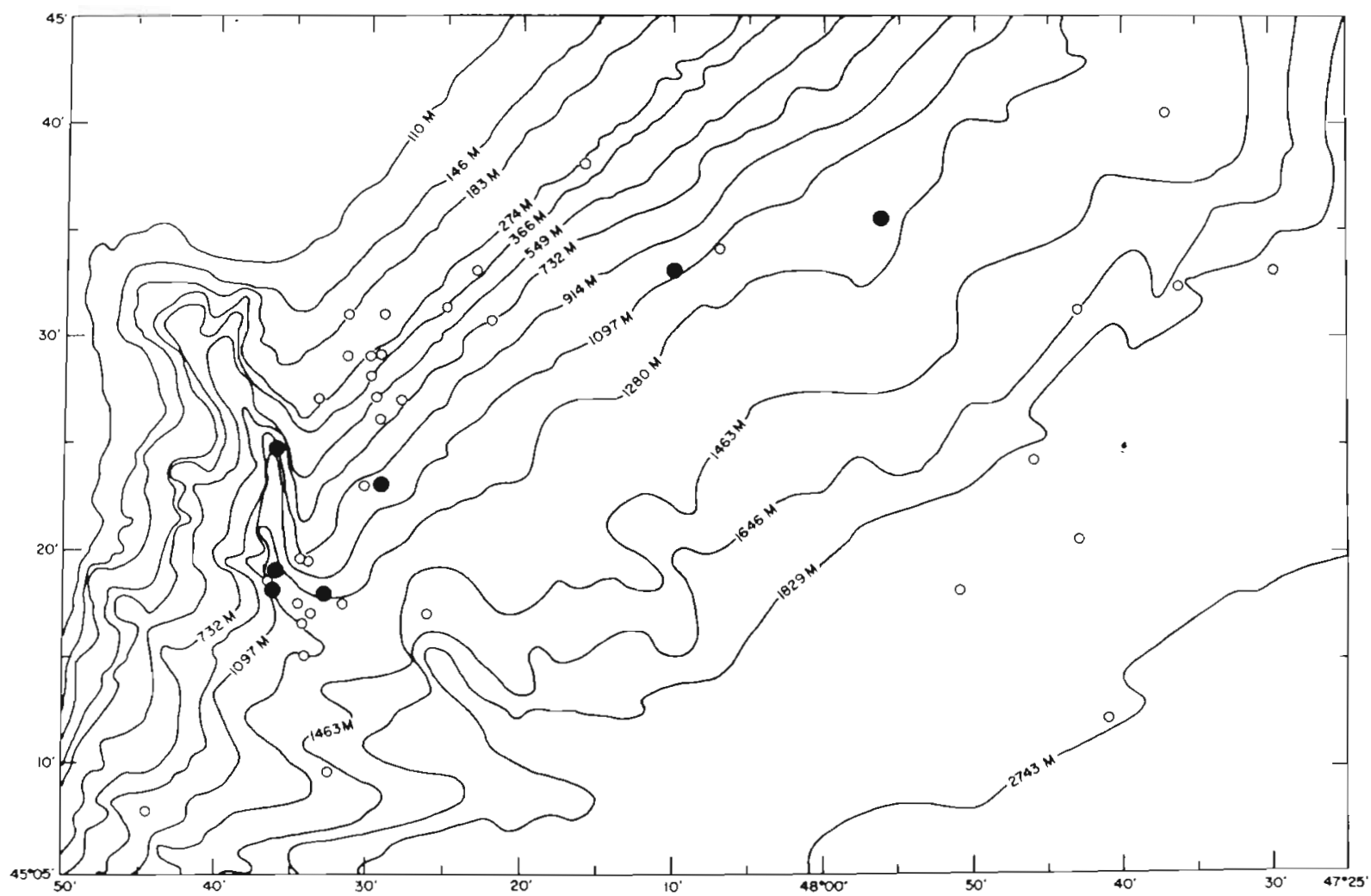

Fig. 1. Locations of deep-trawling stations in the Carson Canyon region. Closed circles: collections taking nuculanids 
umbo made counts on 4 specimens unreliable; these were omitted from the analyses. External growth checks were identified and counted prior to sectioning. Heavy shell erosion prevented ageing on 14 valves. An additional 30 specimens were aged using this method. Longitudinal sections could not be prepared from Nuculana due to shell fragility, but external growth checks were counted from 160 individuals. Shell erosion made determination of prodissoconch size on both species impossible.

\section{RESULTS}

Morphometric data for both species are presented in Table 2, with length frequencies plotted in Fig. 2. The size distribution of Nuculana pernula is characterized

Table 2. Morphometric data for Nuculana pernula ( $\mathrm{n}=183$ ) and Yoldia thraciaeformis $(\mathrm{n}=149$ ) from Carson Canyon. Range of measurements in parentheses

\begin{tabular}{|ccc|}
\hline & $\begin{array}{c}\text { Nuculana } \\
\text { pernula }\end{array}$ & $\begin{array}{c}\text { Yoldia } \\
\text { thraciaeformis }\end{array}$ \\
\hline Length (mm) & $25.6 \pm 2.2$ & $40.5 \pm 5.6$ \\
& $(17.1-30.2)$ & $(25.9-54.5)$ \\
Height (mm) & $13.0 \pm 1.3$ & $25.1 \pm 3.4$ \\
& $(7.8-15.5)$ & $(16.0-32.7)$ \\
Width (mm) & $8.2 \pm 1.1$ & $16.9 \pm 2.5$ \\
& $(4.3-10.0)$ & $(10.5-22.4)$ \\
Height : Length & $0.51 \pm 0.02$ & $0.62 \pm 0.03$ \\
& $(0.44-0.57)$ & $(0.56-0.67)$ \\
Width : Length & $0.32 \pm 0.03$ & $0.42 \pm 0.03$ \\
& $(0.23-0.39)$ & $(0.31-0.46)$ \\
Width : Height & $0.63 \pm 0.04$ & $0.68 \pm 0.05$ \\
& $(0.51-0.77)$ & $(0.46-0.74)$ \\
\hline
\end{tabular}

by an abundance of large individuals and a high degree of clustering around a single mode. Only 6 $(3.3 \%)$ of 183 specimens have lengths under $20 \mathrm{~mm}$ and $62 \%$ of the population fall within a $2 \mathrm{~mm}$ size class (25 to $27 \mathrm{~mm}$ ). The length frequency distribution of Yoldia thraciaeformis is dominated by even larger individuals. Two $(1.3 \%)$ of 149 specimens have lengths under $30 \mathrm{~mm}$ and $47 \%$ of the population fall within a $6 \mathrm{~mm}$ size class ( 35 to $41 \mathrm{~mm}$ ). For both species there are few individuals of lengths between 29 and 31 $\mathrm{mm}$.

The inferred ages of Nuculana pernula range from 3 to 11 bands and are normally distributed about a mean of $6.7 \pm 1.4$ (Fig. 3). Growth is rapid (5.5 mm band ${ }^{-1}$ ) until Band 4 and decreases to $1 \mathrm{~mm}^{\text {band }}{ }^{-1}$ from Bands 4 to 11 (Fig. 4). Numbers of external growth checks are significantly correlated with shell length $(r=0.64$, $\mathrm{p}<.01$ )

The internal and external age determinations of Yol-

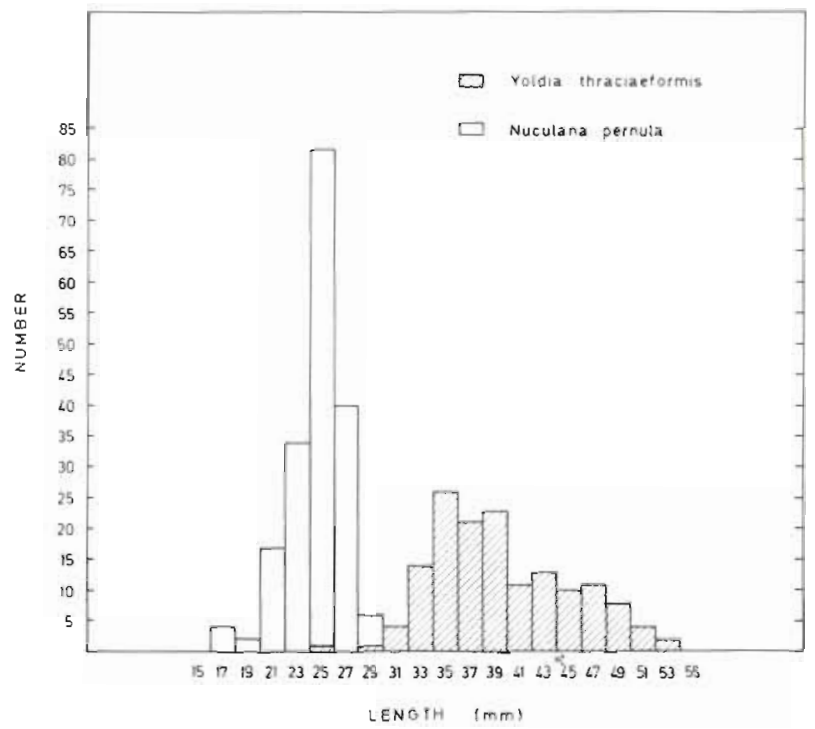

Fig. 2. Nuculana pernula and Yoldia thraciaeformis. Length frequency distributions for specimens examined in this study. $N$. pernula $\mathrm{n}=183 ; Y$. thraciaeformis $\mathrm{n}=149$

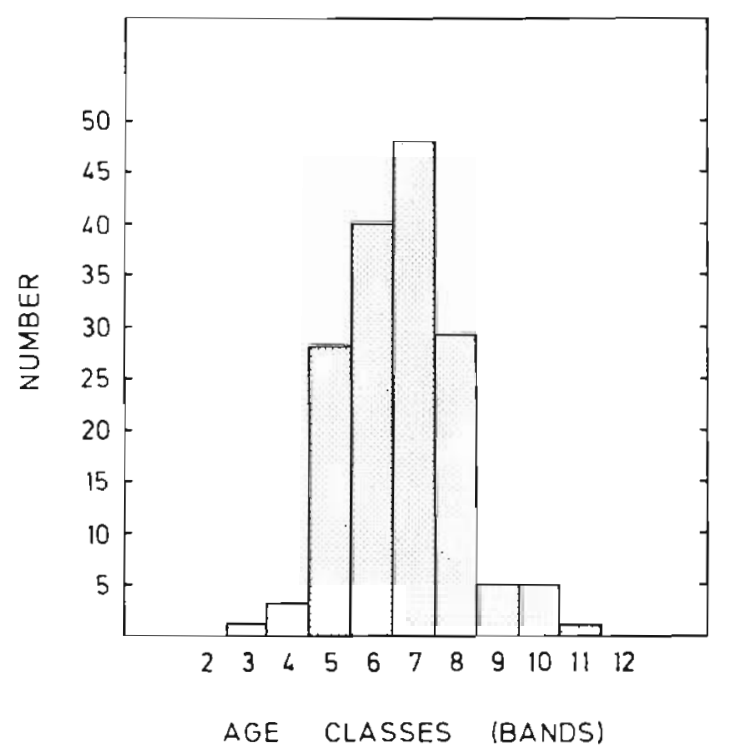

Fig. 3. Nuculana pernula. Ages determined using external bands. $\mathrm{n}=160$

dia thraciaeformis warrant separate treatment since it is not known whether their origins are identical. Data derived from external counts indicate that the age class structure approaches a normal distribution (Fig. 5A) having a mean age of $7.8 \pm 2.2$ bands (range 4 to 14 ). Growth is rapid at $7.5 \mathrm{~mm}$ band $^{-1}$ during the first 4 age classes but decreases to $2.3 \mathrm{~mm}^{\text {band }}{ }^{-1}$ and then 0.5 $\mathrm{mm}_{\text {band }}{ }^{-1}$ for age classes 4 to 11 and 11 to 15 respectively (Fig. 6). Numbers of external growth checks are significantly correlated with shell length $(r=0.66$, $\mathrm{p}<.01)$.

The age frequency distribution of Yoldia thraciaefor- 


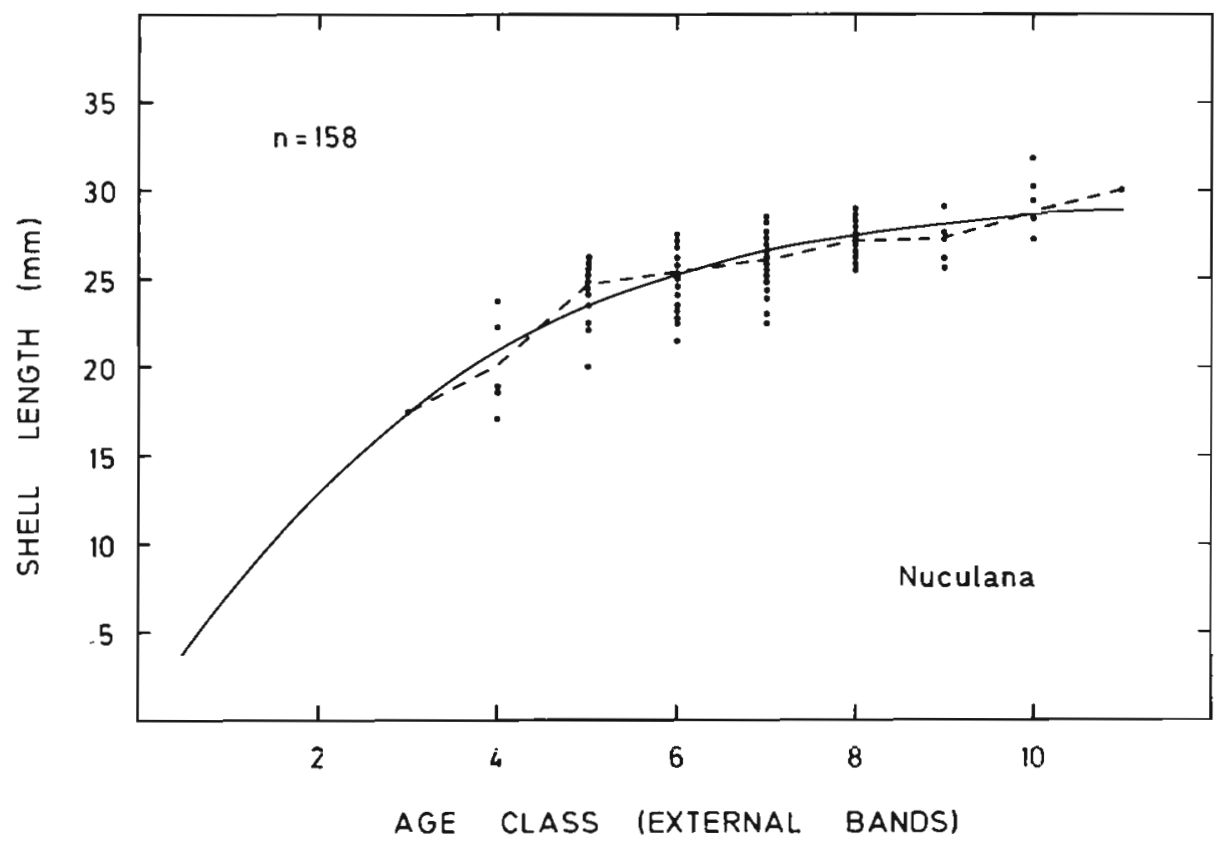

Fig. 4. Nuculana pernula. Shell length plotted against number of external bands. Broken line: mean length at given age. Solid ine: tentative growth curve fitted by eye. Number of observations $=$ $\mathrm{n}$

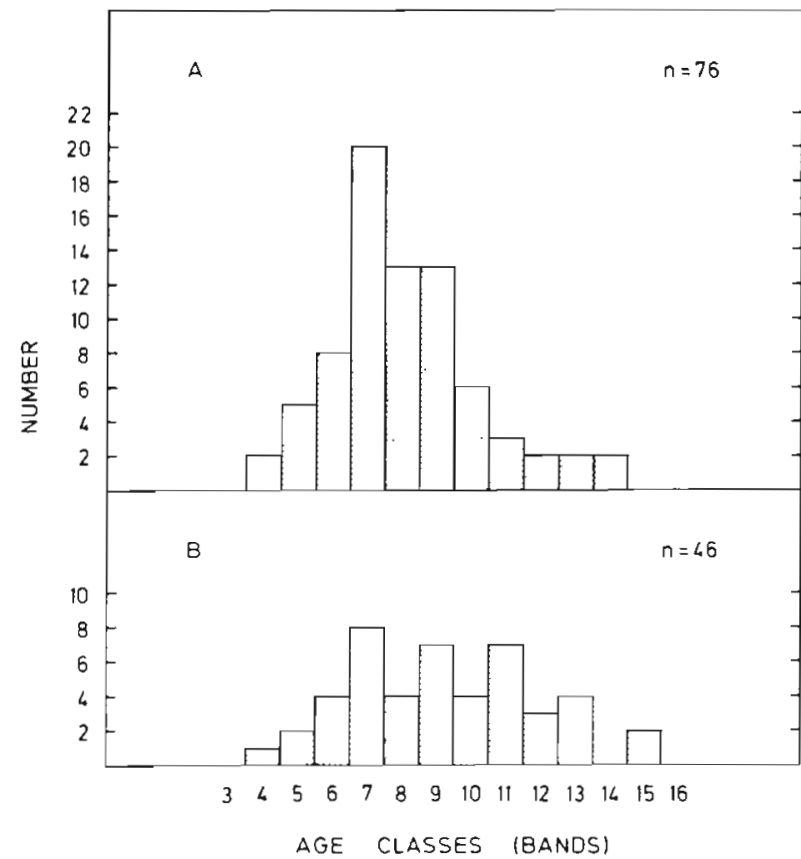

Fig. 5. Yoldia thraciaeformis. (A) Ages determined from external bands; (B) ages determined from sections

mis based upon internal counts has no obvious modal structure (Fig. 5B). The mean age is $9.2 \pm 2.7$ bands (range 4 to 15 ) and band number was significantly correlated with shell length $(r=0.47, p<.01)$. Differences between the mean length at each age class are not significant between the 2 methods (Student's t-test, $p>.05)$. Mean lengths per age class for both species are presented in table 3 .

Meat dry weights represented by each size class of
Nuculana pernula and Yoldia thraciaeformis were recorded to an accuracy of $0.01 \mathrm{~g}$. The empirical relations between ${ }^{10} \log$ meat dry weight (y) and ${ }^{10} \log$ shell length $(\mathrm{x})$ for $N$. pernula and $Y$. thraciaeformis were calculated to be $y=3.32 \mathrm{x}-5.70\left(\mathrm{~N}=10, \mathrm{r}^{2}=0.66\right)$ and $y=1.86 x-3.05\left(N=10, r^{2}=0.49\right)$ respectively.

Small, round impressions and holes were found in shells of dead Nuculana pernula. These impressions/ holes possessed concentric rings decreasing in diameter and beveled outer edges. Small areas of the internal shell surfaces were yellow in colour.

Soft tissues of both species were examined macroscopically to determine the state of maturity. None showed evidence of any gonadal development.

\section{DISCUSSION}

The growth bands of Nuculana pernula and Yoldia thraciaeformis may be deposited annually in association with spawning (Jones et al., 1978) or reductions in food supply (Williamson and Kendall, 1981). Seasonal spawning has been observed in a number of deep-sea animals, including brittle stars, an isopod crustacean, and other bivalves (Lightfoot et al., 1979). Even in the deepest water, in areas usually considered extremely unvarying, seasonal signals have now been detected (Dickson et al., 1982). Radioisotopic studies (Turekian et al, 1982) have determined that deep-water (>55 m) specimens of the ocean quahog Arctica islandica form annual growth increments in concert with the seasonally fluctuating supply of bomb ${ }^{14} \mathrm{C}$ to North Atlantic surface waters. Deuser et al. (1981) sampled the par- 
Fig. 6. Yoldia thraciaeformis. Shell length plotted against number of external bands. Broken line: mean length at given age. Solid line: tentative growth curve fitted by eye. Number of observations $=\mathrm{n}$

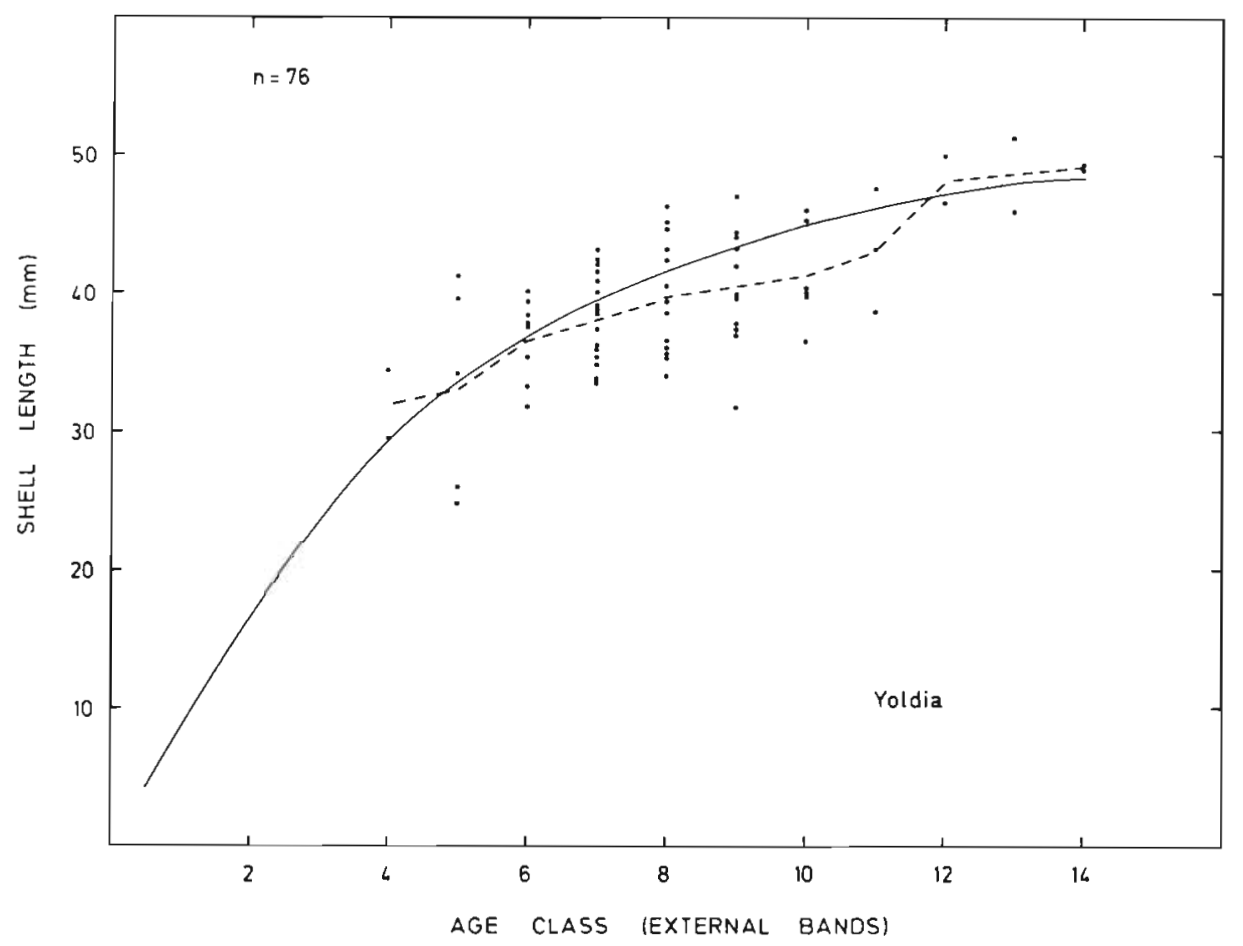

ticulate flux in the Sargasso Sea at a depth of $3200 \mathrm{~m}$ and found that all major components of the sediment, including organic matter and calcium carbonate, arrived at the bottom in a seasonally fluctuating manner. The environment of Carson Canyon is highly seasonal at the surface, and there is no reason to doubt that seasonal influences extend to slope depths. One manifestation of this would be the growth checks we observe on the nuculanids.

The absence of small individuals in the populations of Nuculana pernula and Yoldia thraciaeformis cannot be attributed to gear selectivity because other smaller molluscs were collected in the same trawl collections (e.g. Natica pusilla, $5 \mathrm{~mm}$ length). Heavy predation by boring gastropods and benthic fish is proposed to be a major factor in restricting the numbers of small $N$. pernula and $Y$. thraciaeformis in Carson Canyon. The round impressions/holes found in Nuculana valves are characteristic of naticid boreholes and the yellow colour on the inner shell surfaces was probably produced by the acid secretions of a carnivorous gastropod (M. R. Carriker, pers. comm.). Temperatures in Carson Canyon are within recorded minima for naticacean boring (Carriker, 1981) and maximum depth ranges of boring gastropods (Carriker, 1961), as evidenced by our collection of Natica from $1460 \mathrm{~m}$ (station 838). The drill Urosalpinx prefers young, rapidly growing oysters and responds positively to oxaloacetic acid, an end product in the metabolism of shell formation, with the strength of the response proportional to the growth rate of the prey (Blake, 1960). A single Y. thraciaeformis
(10 mm length) and several specimens of the bivalve Nucula sp. (2 to $3 \mathrm{~mm}$ length) were found in stomachs of the macrourid fish Macrourus berglax $(10-37 \mathrm{~cm}$ pre-anal length) collected in the canyon.

Intense predation early in life should select for individuals with rapid growth rates if the sizes attained substantially reduce the vulnerability of such individuals to predation. The mussel Modiolus modiolus puts all of its energy into growth for 4 to 6 yr before maturing at a size where predation is reduced (Seed and Brown, 1978). The cockle Clinocardium nuttallii grows very rapidly out of the size range of fish and crab predation into that of gull predation where the probability of survival is greater (Gallucci and Gallucci, 1982). Both Nuculana pernula and Yoldia thraciaeformis experience rapid growth until the age of 4 yr (Fig. 5), possibly reflecting a similar growth strategy. Neilson's (1975) observations on the ability of $N$. pernula (23 to $28 \mathrm{~mm}$ length) to leap away from Buccinum undatum lend credence to this argument. Similar escape behaviour has also been recorded for Yoldia limatula (Drew, 1900).

Population structures similar to those of Nuculana pernula and Yoldia thraciaeformis have been previously documented. Larger individuals are numerically predominant in populations of other protobranchs throughout the Atlantic (Allen and Sanders, 1973). Deep-sea collections of the tanaid crustacean Neotanais (Grassle and Sanders, 1973) and the snail Benthonella tenella (Rex et al., 1979) off Bermuda have contained relatively few young individuals. Size fre- 


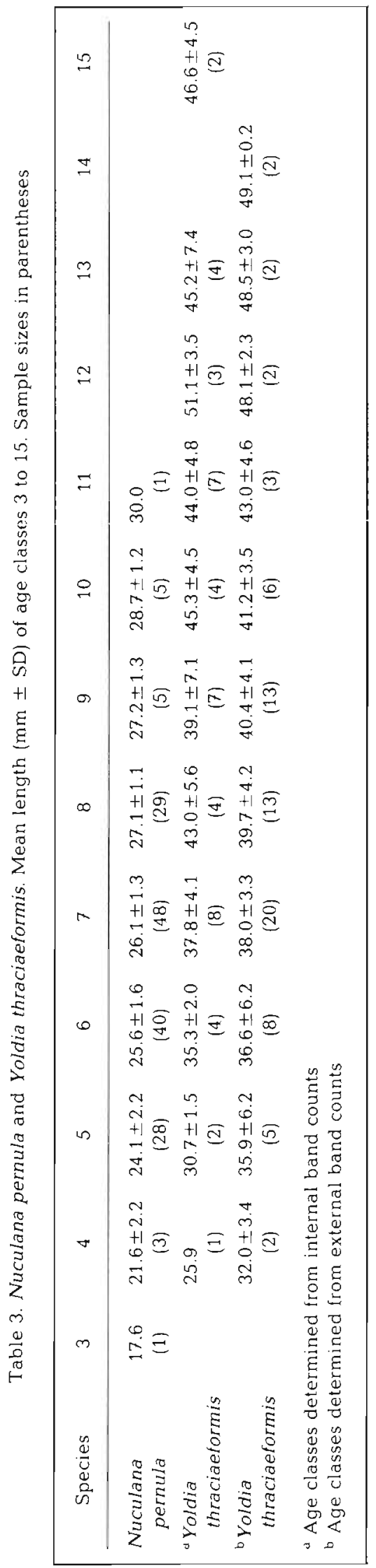

quency distributions of some deep-sea echinoderm populations are also dominated by larger individuals (Tyler and Pain, 1982).

Because similar population patterns are found in both places, the rationale used to explain patterns in the Arctic, for which supporting data exist, may extend to the deep sea. Populations of three salmonids in the Northwest Territories are characterized by a numerical predominance of older, larger individuals, high degree of clustering around modal length values, and considerable variation in age at a given length (Johnson, 1976, 1981). Johnson (1976) identified the standing wave' for length and age as being characteristic of unexploited populations 'limited by resources to a fixed establishment'. He postulated that only such recruitment as is necessary to achieve equilibrium with mortality takes place. A consequence is that an increase in growth rate would be expected at the size of recruitment. Heavy predation on small bivalves would select against such a controlled recruitment in Nuculana pernula and Yoldia thraciaeformis.

Nuculana pernula and Yoldia thraciaeformis attain sizes in Carson Canyon considerably larger (2 to 25 times) than any other deep-sea bivalves we have sampled previously, including from Hudson Canyon (e.g. Rowe et al., 1982). The sizes we observed, however, are not remarkably larger than those reported for these species in shallow areas. Maximum lengths of $N$. pernula from 5 Arctic-Subarctic regions ranged from 20 to $30 \mathrm{~mm}$ (Lubinsky, 1980). Madsen (1949) reports a maximum length of $29 \mathrm{~mm}$ in Icelandic waters and Ocklemann (1958) records a length of $34 \mathrm{~mm}$ off East Greenland. Maximum lengths of $Y$. thraciaeformis range from $43 \mathrm{~mm}$ off East Greenland (Ocklemann, 1958) to $71 \mathrm{~mm}$ in the northwest Atlantic (Gould, 1870). The depth range of $Y$. thraciaeformis is extended to $1500 \mathrm{~m}$ from $418 \mathrm{~m}$.

The ages and growth rates of the deep-sea Nuculana pernula and Yoldia thraciaeformis were not remarkably different from what would be expected in shallow-living species. $N$. pernula from 50 to $100 \mathrm{~m}$ off Sakhalin (Skalkin and Tabunkov, 1969: 1151; Table 1) have a growth curve almost identical to the one we find, and reach 9 years of age. (Tabunkov, 1974, revises these rates arguing that 2 growth rings are laid down each year; we do not find the data convincing). $N$. minuta from the Clyde Sea (Ansell and Parulekar, 1978) grow at a lesser rate than does our $N$. pernula but reaches the same age. $Y$. limatula from Prince Edward Island (Lewis et al., 1982) grow at about the same rate as our $Y$. thraciaeformis but only attain $4 \mathrm{yr}$ of age. Much remains to be found out about growth rates in the deep sea, but accumulating evidence (Rowe, 1983) indicates that extreme longevity may be the exception rather than the rule. 
Lubinsky (1980) identifies a latitudinal succession of subspecies of Nuculana pernula from the Canadian Arctic to the Gulf of Maine. Inclusion of the Carson Canyon data supports the trend which she observed towards a broader shell from the Canadian Archipelago to South Labrador and a subsequent narrowing of the shell farther south to the Gulf of Maine (Fig. 7).

Whenever abundant, Nuculana pernula and Yoldia thraciaeformis were collected together (Table 1). Although we cannot rule out small-scale patchiness, it would seem that they share similar if not identical habitats. These are probably soft sediment pockets of restricted area, for example in the axis of the canyon (Fig. 1). Attempts to resample the populations from R/V 'Oceanus' in September 1982 were unsuccessful. The size frequency distributions show very little overlap in lengths between the two species. The factors which reduce niche overlap must then be size-related. A high degree of clustering and high SD values associated with the mean lengths per age class suggest that forces on the individual to achieve and retain a certain size are much greater than the tendency for the individual to increase regularly in length with time (Johnson, 1976). These forces would include the factors alluded to above and a growth strategy designed to reduce mortality from predation. Rex (1979) found that slope populations of the benthic snail Alvania pelagica devoted relatively more energy to growth and less to reproduction than shelf populations of the same species. He interpreted these life-history patterns as evidence for $\mathrm{K}$-selection on what he considered to be the environmentally stable slope and r-selection on the unstable shelf. Comparative studies of this sort on $N$. pernula and $Y$. thraciaeformis, which occur both in shallow shelf waters and in the deep sea, would be instructive.

Acknowledgements. We are grateful to Sally Babie for help at sea and in the laboratory, and to Kent Gilkinson for aiding in the cutting and interpretation of shell sections. Useful comments on the manuscript were provided by John D. Gage, Robert Hessler, Lionel Johnson, Michael A. Rex, and Gilbert $T$. Rowe. The work was supported by Natural Sciences and Engineering Research Council grant A-7230. This is NICOS Contribution Number 49 .

\section{LITERATURE CITED}

Allen, J. A., Sanders, H. L. (1973). Studies on deep-sea Protobranchia (Bivalvia); the families Siliculidae and Lametilidae. Bull. Mus. comp. Zool. 145: 263-310

\begin{tabular}{|c|c|c|c|c|c|c|c|c|}
\hline \multirow[t]{2}{*}{ REGION } & \multirow{2}{*}{$\begin{array}{l}\text { NUMBER OF } \\
\text { SPECIMENS }\end{array}$} & \multirow{2}{*}{$\begin{array}{l}\text { LENGTH } \\
\text { (mm! }\end{array}$} & \multicolumn{6}{|c|}{ RATIO } \\
\hline & & & .40 & .45 & .50 & .55 & .60 & .65 \\
\hline $\begin{array}{l}\text { Conadran } \\
\text { Archipelago }\end{array}$ & 15 & $17-23$ & $\ldots$ & 1 & - & & & \\
\hline $\begin{array}{l}\text { Foxe Bosin } \\
\text { Hudson Bay }\end{array}$ & 40 & $21-30$ & & & & & & $\mathrm{H}: \mathrm{L}$ \\
\hline $\begin{array}{l}\text { North } \\
\text { Labrador }\end{array}$ & 30 & $18-28$ & & & & & - & \\
\hline $\begin{array}{l}\text { South } \\
\text { Labrador }\end{array}$ & 20 & $10-20$ & & & & 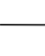 & 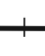 & \\
\hline $\begin{array}{l}\text { Carson Canyon } \\
\text { Grand Banks }\end{array}$ & 183 & $17-30$ & & & & & & \\
\hline $\begin{array}{l}\text { Gulf of } \\
\text { Maine }\end{array}$ & 45 & $10-22$ & & & & & & \\
\hline & & & .20 & .25 & .30 & .35 & .60 & .45 \\
\hline $\begin{array}{l}\text { Canadian } \\
\text { Archipelago }\end{array}$ & 15 & $17-23$ & & & & & & \\
\hline $\begin{array}{l}\text { Foxe Basin } \\
\text { Hudson Bay }\end{array}$ & 40 & $21-30$ & & & & 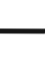 & & $W: L$ \\
\hline $\begin{array}{l}\text { North } \\
\text { Lobrador }\end{array}$ & 30 & $18-28$ & & & & & & \\
\hline $\begin{array}{l}\text { South } \\
\text { Labrador }\end{array}$ & 20 & $10-20$ & & & & & & \\
\hline $\begin{array}{l}\text { Carson Conyon } \\
\text { Grand Banks }\end{array}$ & 183 & $17-30$ & & & & & & \\
\hline $\begin{array}{l}\text { Gulf of } \\
\text { Maine }\end{array}$ & 45 & $10-22$ & & & & & & \\
\hline
\end{tabular}

Fig. 7. Nuculana pernula. Height-to-length $(\mathrm{H}: \mathrm{L})$ and width-to-length $(\mathrm{W}: \mathrm{L})$ ratios for populations arranged in order of decreasing latitude. Data other than our own are from Lubinsky (1980) 
Ansell, A. D., Parulekar, A. H. (1978). On the rate of growth of Nuculana minuta (Müller) (Bivalvia; Nuculanidae). J. moll. Stud. 44: 71-82

Bayne, B. L. (1976). Marine mussels: their ecology and physiology. Cambridge University Press, Cambridge

Blake, J. W. (1960). Oxygen consumption of bivalve prey and their attractiveness to the gastropod, Urosalpinx cinerea. Limnol. Oceanogr. 5: 273-280

Byran, C. W. (1969). The effects of oil-spill removers ('detergents') on the gastropod Nucella lapillus on a rocky shore in the laboratory. J. mar. biol. Ass. U. K. 49: 1067-1092

Carriker, M. R. (1961). Comparative functional morphology of boring mechanisms in gastropods. Am. Zool. 1: 263-266

Carriker, M. R. (1981). Shell penetration and feeding by naticacean and muricacean predatory gastropods: a synthesis. Malacologia 20: 403-433

Deuser, W. G., Ross, E. H., Anderson, R. F. (1981). Seasonality in the supply of sediment to the deep Sargasso Sea and implications for the rapid transfer of matter to the deep ocean. Deep Sea Res. 28A: 495-505

Dickson, R. R., Gould, W. J., Gurbutt, P. A., Killworth, P. D. (1982). A seasonal signal in ocean currents to abyssal depths. Nature, Lond. 295: 193-198

Drew, G. A. (1900). Locomotion in Solemya and its relatives. Anat. Anz. 17: 257-266

Gallucci, V. F., Gallucci, B. B. (1982). Reproduction and ecology of the hermaphroditic cockle Clinocardium nuttalii (Bivalvia: Cardiidae) in Garrison Bay. Mar. Ecol. Prog. Ser. 7 : $137-145$

Gould, A. A. (1870). Report on the invertebrata of Massachusetts. Wright and Potter, Boston

Grassle, J. F., Sanders, H. L. (1973). Life histories and the role of disturbance. Deep Sea Res. 20: 643-659

Haedrich, R. L., Rowe, G. T., Polloni, P. T. (1980). The megabenthic fauna in the deep sea south of New England, USA. Mar. Biol. 57: 165-179

Johnson, L. (1976). Ecology of Arctic populations of lake trout, Salvelinus namaycush, lake whitefish, Coregonus clupeaformis, Arctic char, $S$. alpinus, and associated species in unexploited lakes of the Canadian Northwest Territories. J. Fish. Res. Bd Can. 33: 2459-2488

Johnson, L. (1981). The thermodynamic origin of ecosystems Can. J. Fish. aquat. Sci. 38: 571-590

Jones, D. S. (1980). Annual cycle of shell growth increment formation in two continental shelf bivalves and its paleoecologic significance. Paleobiology 6: 331-340

Jones, D. S., Thompson, I., Ambrose, W. (1978). Age and growth rate determinations for the Atlantic surf clam Spisula solidissima (Bivalvia: Matracea), based on internal growth lines in shell cross-sections. Mar Biol. 47: $63-70$

Lewis, J. B., Saleh, S., Reiswig, H. M., Lalli, C. M. (1982). Growth, production, and biomass of the burrowing protobranch mollusc Yoldia limatula in the Bideford River, Prince Edward Island. Canada. Mar. Biol. 70: 173-179

Lightfoot, R. H., Tyler, P., Gage, J. D. (1979). Seasonal reproduction in deep-sea bivalves and brittlestars. Deep Sea Res, 26A: $967-973$

Lubinsky, I. (1980). Marine bivalve mollusca of the Canadian central and eastern Arctic: faunal composition and zoogeography. Can. Bull. Fish. Aquat. Sci. 207

Lutz, R. A. (1976). Annual growth patterns in the inner shell layer of Mytilus edulis L. J. mar. biol. Ass. U. K. 56: $723-731$

Madsen, F. J. (1949). Marine bivalvia. In: Frioriksson, A., Tuxen, S. L. (ed.) The zoology of Iceland, Vol. 4, Part 63 Munksgaard, Copenhagen, p. 1-116

Nielson, C. (1975). Observations on Buccinum undatum attacking bivalves and on prey responses, with a short review on attack methods of other prosobranchs. Ophelia 13: $87-108$

Ocklemann, W. K. (1958). The zoology of East Greenland Marine Lamellibranchiata. Medd. Grønland 122: 1-256

Rex, M. A. (1979). r-and K-selection in a deep-sea gastropod Sarsia 64: 29-32

Rex, M. A., Van Ummersen, C. A., Turner, R. D. (1979) Reproductive pattern in the abyssal snail Benthonella tenella (Jeffreys). In: Stancyk, S. E. (ed.) Reproductive ecology of marine invertebrates. University of South Carolina Press, Columbia, p. 173-188

Rowe, G. T (1983). Biomass and production of the deep-sea macrobenthos. In: Rowe, G. T. (ed.) Deep-sea biology. The sea, Vol. 8. John Wiley and Sons, New York, p. 97-121

Rowe, G. T., Polloni, P. T., Haedrich, R. L. (1982). The deepsea macrobenthos on the continental margin of the northwest Atlantic Ocean. Deep Sea Res. 29: 257-278

Seed, R., Brown, R. A. (1978). Growth as a reproductive strategy for survival in two marine bivalves, Cerastoderma edule and Modiolus modiolus. J. Anim. Ecol. 47; 283-292

Skalkin, V A., Tabunkov, V D. (1969). Biology, distribution and reserves of Nuculana pernula (Taxodonta, Nuculanidael of the south-eastern littoral of Sakhalin. Zool. Zhur, 48: 1147-1155

Tabunkov, V. D. (1974). Growth, production characteristics, and development of the population of Nuculana pernula (Taxodonta, Nuculanidae) of south-eastern Sakhalin. Zool. Zhur. 53: 1616-1622

Theisen, B. F. (1973). The growth of Mytilus edulis L. (Bivalvia) from Disko and Thule district, Greenland. Ophelia 12: $59-78$

Theroux, R. B., Wigley, R. L. (1983). Distribution and abundance of east coast bivalve mollusks based on specimens in the National Marine Fisheries Service Woods Hole Collection. NOAA Technical Report NMFS SSRF-768: 1-172

Turekian, K. K., Cochran, J. K., Nozaki, Y., Thompson, I., Jones, D. S. (1982). Determination of shell deposition rates of Arctica islandica from the New York Bight using natural ${ }^{228} \mathrm{Ra}$ and ${ }^{228} \mathrm{Th}$ and bomb-produced ${ }^{14} \mathrm{C}$. Limnol. Oceanogr. 27: 737-741

Tyler, P. A., Pain, S. L. (1982). The reproductive biology of Plutonaster bifrons, Dytaster insignis, and Psilaster andromeda (Asteroidea: Astropectinidae) from the Rockall Trough. J. mar. biol. Ass. U. K. 62: 869-887

Williamson, P., Kendall, M. A. (1981). Population age structure and growth of the trochid Monodonta lineata determined from shell rings. J. mar. biol. Ass. U. K. 61: $1011-1026$ 